\title{
複写防止用紙の現状と技術動向
}

(株リコー化成品技術研究所 川村栄一

\section{Technological Trends on the Anti-Photocopying Paper}

\author{
Eiichi Kawamura \\ Chemical Products R \& D Center Ricoh Company, Ltd.
}

\begin{abstract}
Due to the unexpected development of high quality photocopier machines, a strong interest towards development of anti-photocopying technology has arisen. High quality photocopiers make it unduly easy for someone to make unauthorized copies out of confidential documents, thus effective countermeasures have become necessary. However, though many attempts have been made to accomplish such countermeasures, the effective protection against these acts is still insufficient.
\end{abstract}

As a result, the number of patents related to this field has recently increased dramatically.

This paper is a summary of the patents and describes the technological trends on the anti -photocopying paper.

\section{1.はじめに}

近年の情報化社会による情報量の増大，情報の共有 化，情報伝達手段の多様化と共に複写機の普及，性能 向上は飛躍的で, それに伴って文書の機密保持, 出版 物の違法複写防止等に対する関心が急速に高まり，政 府・官公庁, 一般企業, 出版業界, その他多くの分野 で複写防止, 偽造防止用紙に対する要望が強くなって いる。

1990 年度の複写機国内生産は約 240 万台と前年比 $6.3 \%$ 伸びであり，その $95 \%$ 以上を占める間接静電 複写方式いわゆる普通紙複写機 (PPC) は高速, 高品 質化, 多機能化, 複合化, デジタル化, カラー化等性 能の向上及び機能の付加は一段と進む傾向にある。特 に高級機にはデジタル化が採用されてきているが, 現 在のところ事務用複写機の大部分は従来からのアナロ グ方式が主流となっており, 今後も続くものと予想さ れる。

本来, 複写機の使命はどのような原稿からでも忠実 に再現した複写物が得られることであり，それを目標 に技術開発が進められてきたが，現在では原稿以上の 品質の複写物やユーザーの好みの複写物を作成するこ とも可能であり，この傾向はさらに進むものと考えら れ, 当然, 複写防止用紙, 偽造防止用紙の開発と複写 機との開発とは結果的には互いに開発競争となってい
るのが実状である。このような背景から複写防止，偽 造防止の方式には非常に多くの提案がなされているが 実用化されている方式は少なく, 特に市場が求めてい る複写防止性能は十分とは言えない。

本稿では過去 20 年間の特許情報を中心に, 間接静電 複写機（PPC）による複写防止用紙に関する技術動向 について方式別に紹介し, 現状と課題について考察し てみたい。

\section{2. 複写防止方式の分類}

特許上からは複写防止と偽造防止を明確に区別され ていないものもあるが, 複写防止という観点から見る と複写防止とは複写物の内容が判読できない状態にあ ることが必要で, 例えば複写すると複写物全面が真つ 黒に複写され全く情報が複写されないもので, 理想的 には原稿は明膫に判読できるが複写物は全く判読出来 ないものであり，一方，偽造防止は複写物の内容は判 読できても明らかに偽造したものであることが直ぐ判 明できる状態にあるもので，例えば複写すると無効， コピー不可等のかくし文字が複写物に現われ，偽物で あることが一目瞭然となるものである。

偽造防止用紙は証明書や証券印刷等に以前から用い られており, 出願件数も多いが, 複写防止に関する特 許も最近は年 20 件以上の公開がある。

特許に提案されている主な複写防止方式を分類した 


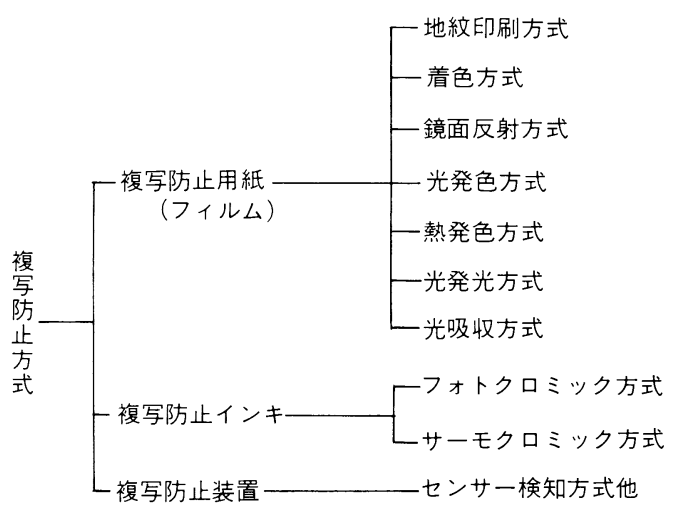

図 1 複写防止方式の分類

結果を図 1 に示す。

複写防止用品について大別すると用紙，フィルム， インキおよび装置を用いるものに区分される。フィル ムはそれ自体を用いる場合と文書の全面または必要部 分にのみ貼り合わせる等して用いる場合とがあるが， 全て用紙の中に包含した。複写防止用紙には印刷, 手 書き，ワープロその他の手段によって複写防止原稿を 作成するための複写防止用紙と原稿から複写機 (PPC) によって複写防止書類を作成するための再複 写防止用紙とに分けられ，要求性能上多少の違いは あっても，ともに複写防止が目的であり同様に扱うこ とにした。また，厳密には偽造防止に含まれる方式も あるが，複数の複写防止方式との組み合せで，上り効 果を求めた提案もあり，複写防止方式の一つとして
扱つた。

次に各方式別に概略と技術動向について紹介する。

\section{1 地紋印刷方式}

この方式は古くから偽造防止として証券印刷に用い られる用紙などに使用されている。本来は偽造防止を 目的としたものであるために，複写防止の目的には他 の方式と組み合わせた補助的な方式で実用化されてい る。特徵は用紙に原稿の判読には支障のない程度に彩 紋と呼ばれる幾何学細密模様が網点等で地紋やかくし 文字印刷されたもので，複写すると模様或いはコピー 不可, VOID, 無効等の文字が鮮明に現われる。特に模 様，色彩等に工夫がなされている。

かくし文字の技術は背景の網点模様と異なる大きさ の網点でかくし文字の潜像を印刷し, 背景と潜像の両 者にかけてカムフラージュパターンを設けることに よって，通常は潜像の存在がはっきりとは認識されな いが, 複写すると大小の網点の一方が再現され他方が 再現されなくなる結果，その明暗の差によって潜像が 明瞭に視認されるものである。

テストの結果では網点地紋印刷がかくしパターンと なるためには，かくし文字線数 133 線以上，背景 65 線 以下ならば複写による再現が可能であった。

この方式は高精度の印刷が要求され，コスト的にも 高く，地紋のために原稿の判読が良好ではなくなり， 単独使用では複写防止も十分ではないが，偽造である ことが明瞭であるために高額の書籍の印刷用紙に使用 されている例もあり，違法複写に対する警告または偽

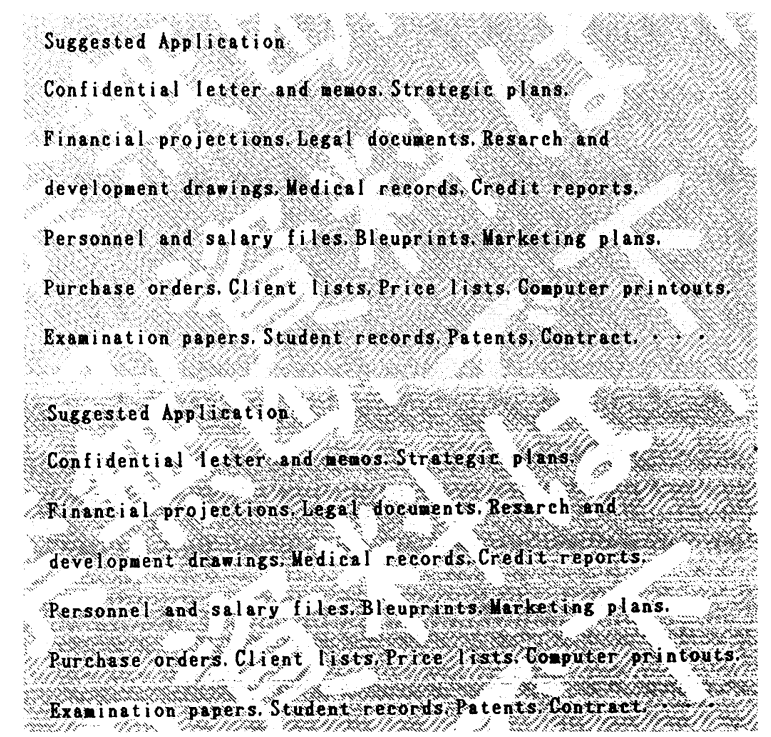

図 2 偽造防止用紙 
造防止には効果が大きいといえる。

図 2 に偽造防止を目的とした用紙を複写してかくし 文字の現われた 1 例を示した。

この方式は偽造防止用紙として，古くから特許出願 は多数なされており，例えば透かし模様が複写物に現

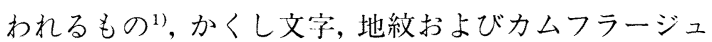
パターン等の組み合わせによるもの2)，特定の網点の 線数, 面積率を使用するもの ${ }^{3)}$, 複数の色, 濃淡を組み 合わせた模様の印刷によるもの4)，あるいは特定の色 素を用いて印刷したもの等，それぞれ特徵を有する 提案がすでになされているが，最近の公開特許から 2 , 3 紹介する。

面積がほぼ等しい2 種類の異なる形状の網点を印刷 したもので，複写機の濃淡設定をどの様に変えても， またオートモードにしても，結局あらゆる濃度レベル においてもかくし文字が現われるもので，網点の大き さが非常に小さくカムフラージュ用網点の必要がない ことを特徵としたもの卢, 紙またはフィルム上に着色 インキを全面的に施し，銀インキで砂や細粒を散布し たような模様や，多くの線や点で網点などを形成した 模様を施したもの 7$) ， 2$ 種類のパターン状網点によっ てかくし文字を印刷した用紙に再現しにくい色相で情 報を記録し，通常の複写濃度では情報を複写できず， 複写濃度を高くして複写した場合にはかくし文字が現 われ複写の不正使用を防止できるもの等の出願の他 に，力ラ一複写機による偽造防止に関するものでは， 複写機では再現されにくい範囲の 150 175 線, 10\%程 度の網点の模様パターンと背景パターンの 2 色で印刷 し，複写するとパターンがいずれも消えて明らかに複 製であることがわかる提案がなされている99。

\section{2 着色方式}

この方式は製造も容易で単純な構成でありながら沉 用性があり複写防止効果が比較的大きいことから，現 在実用化されている方式にはこの着色方式をべースと したものが多く用いられている。原理は特定の染料ま たは顔料等で用紙を着色し，複写の際の照射光線を画 像部および非画像部ともに同等に吸収させてコントラ ストをなくし，感光体への露光に差がないようにして 画像の形成を不可能にするもので，複写物は全面が黒 色となる。

人間の視感度と複写機の感光体の分光感度との違い を利用したものであるが，複写機及び感光体の進歩に よりその差は少なくなり，テス卜の結果では複写不能 とするには反射率を画像部, 非画像部ともに $10 \%$ 以下 にするか，反射率の差を数\%以内にする必要があり， 当然，原稿は読みにくくなる。そのため色相，吸仪波
長域等の上夫による改善の提案がなされてきている。

一般に文書の文字の色は黑色であり，特に再複写防 止の場合には黑色トナーが用いられるので，複写防止 の目的からは用紙の着色色相は照色が理想的であるが, 画像部と非画像部のコントラストがなくなるために原 稿は判読不能となり，いかにして読みやすい原稿で複 写防止をするかが課題となっている。

図３は実用化されている赤褐色に着色された複写防 止用紙の分光反射特性をホした 1 例である。画像部之 同程度の吸仪を得るために可視域の㴬率は $10 \%$ 前 後と低く，濃色であり原稿の判読性は良くない。

図 4 に人間の比視感度特性，図 5 に感光体の分光感 度特性の例を示した。比視感度は明順応最大 $555 \mathrm{~nm}$, 暗順応最大 $507 \mathrm{~nm}$ であり，感光体の感度分布は 400 ７00 nm にある。図6にSe 単層夕イプ感光体と八口 ゲンランプの実効分光感度分布を示したが，感光体は $\mathrm{Se}$ 合金，OPC，a-Si 系と改䭛が加えられてきており， 広いスペクトル尔答が可能であり, 幽像部と非画像部 との分解能も向上している。また複写物の露光目盛り をライト側にすると分光感度は衰波主側にシフトする 傾向がある。

通常の複写機では，特に青及び赤に対する色再現性 を得るために感光域の短波长側および长波言側をカッ

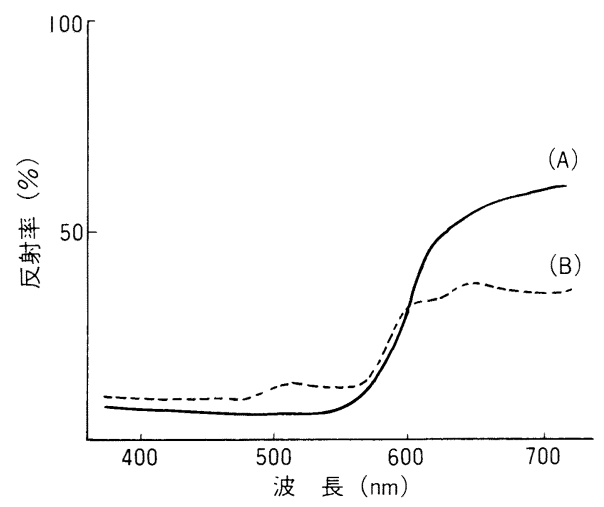

図 3 着色方式分光反射特性例

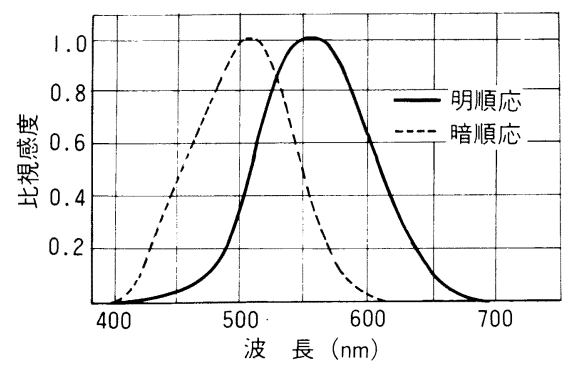

図 4 比視感度特性 


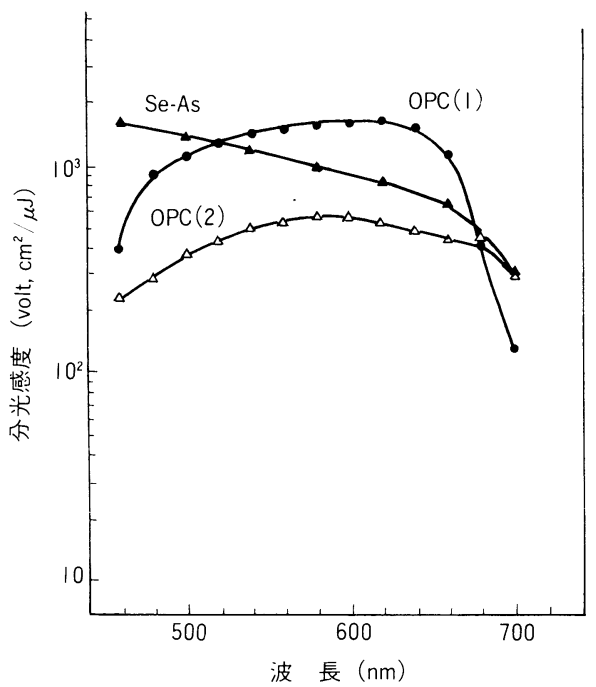

図 5 感光体分光感度

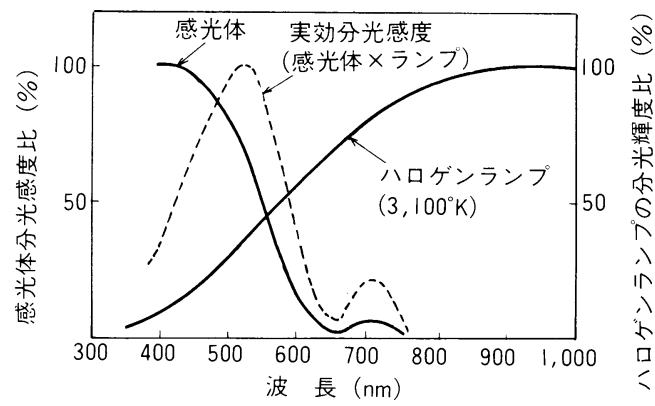

図 6 感光体实效分光感度分布

トして用いられている。そこで着色方式では図 3 の例 に見られるように視感度内のカット部分の波長を利用 して判読性をはドる、大がなされている。この例のA 社（実線）の製品は叮視域の反射率はB社（破線）の ものよりも低いが, 判読性に優れている結果が出てい る。色相の選択にはさらに着色による違和感を少なく 寸るためにも明度, 彩度その他, 嗜好色等からの検討 も必要になってくる。

この方式は複年防止肋紙として多数の出願がされて おり，特に着色材料，着色方法に関する出願が多い。 画像部之非画像部の色の組み合わせによるもので，例 えばほぼ同一の反射摔を份する色相の異なる色素で着 色したもの ${ }^{10)}$ ，570～800 nm の分光反射特性をもつ非 画像部と 400 $570 \mathrm{~nm}$ の分光父射特性をもつ画像部 からなるもの ${ }^{11)}, 400 〜 700 \mathrm{~nm}$ の波䯈の間に最大反射 率を有し, 着色色相に特徵を持なせたもので, 例えば 特定の赤色, 橙色もしくは黄色の着色 ${ }^{12)}$, 視感度の高い 緑系の着色 ${ }^{13)}$, 三原色による反射濃度, 透過濃度の異な

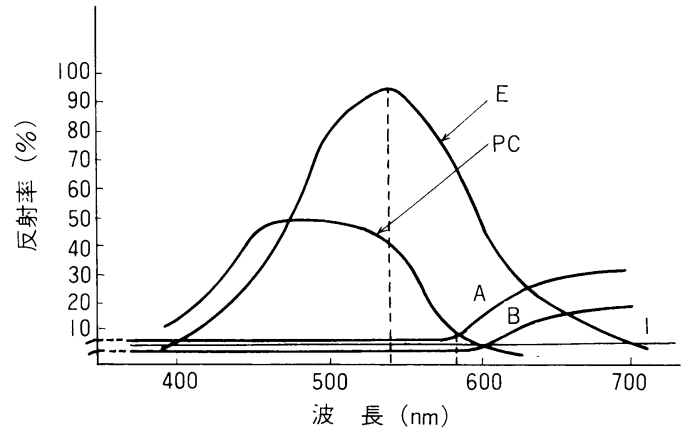

図 7 分光反射特性 ${ }^{19)}$

るセピア調のパターン印刷 ${ }^{14)}$, 明度, 色度, 色差の特定 範乖の濃赤茶色系の着色 ${ }^{15)}$, 特定波長の吸収として 500 ～700 nm の範囲に最大吸収を有する染料を用いる もの ${ }^{16)}$, 特殊顔料として透明ベンガラを用いるもの ${ }^{17)}$, 透過式や反射式の全ての複写を不能としたもので，例 えば両面に異なる色で着色したもの ${ }^{18)} 0.5 〜 50$ 線/ $\mathrm{cm}$ の特定線幅のパターンと 2 種以上の色を用いた出 願 ${ }^{19)}$ がなされている。この特許の分光反射特性の例を 図 7 に示した。この例で全波長域の反射率が約 $6 \%$ の ブラック情報（Ｉ）とカラー $(\mathrm{A}, \mathrm{B})$ とのコントラス トが感光体分光感度 (PC) 外で視感度曲線 (E) 内の 長波長側において差のあることにより原稿の判読が可 能となっている。

鏡面反射方式等との組み合わせによる例として鏡面 反射方式フィルムの欠点である記録情報視認性の改善 を兼ねな出願がなされている。図8-1に示した赤 89 39\%, 黄 10 60\%, 青 20 1\%の特定の着色範楽 (A，B，C，Dで取り囲んな゙斜線部分)で着色を施した 図 8-2 に示した透明ポリエステルフィルム (10 B ) の 表面に微粒子ママット剂入り樹脂薄膜層（30 B）を形成 し, 裏面 $(12 \mathrm{~B})$ には金属薄膜 $(20 \mathrm{~B})$ を蒸着してフィ ルム表面 $(11 \mathrm{~B})$ に着色透明インキ $(40 \mathrm{~B})$ で情報を 印刷しな構成になっている20)。

表面をイエロー1.28, マゼンタ 1.16 , シアン 0.81 程 度の反射濃度值を有するセピア調に着色し，イエロー 0.97 , マゼンタ 0.82 , シアン 0.52 程度のセピア調イン キでパターン印刷し，裹面をイエロー1.05，マゼンタ 0.94, シアン 0.66 程度のセピア調に着色したもの ${ }^{21)}$, さらにこの用紙を熱転写才式で光沢を帯びな記録文字 で印字するもの 22 もある。

その他，フィルムに低い反射レスポンスをもつ色で 着色し判読は裏面より光照射することによって読みや すくして着色方式の久点である原稿の判読性を改善し

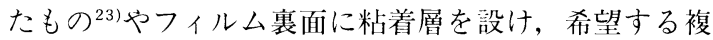




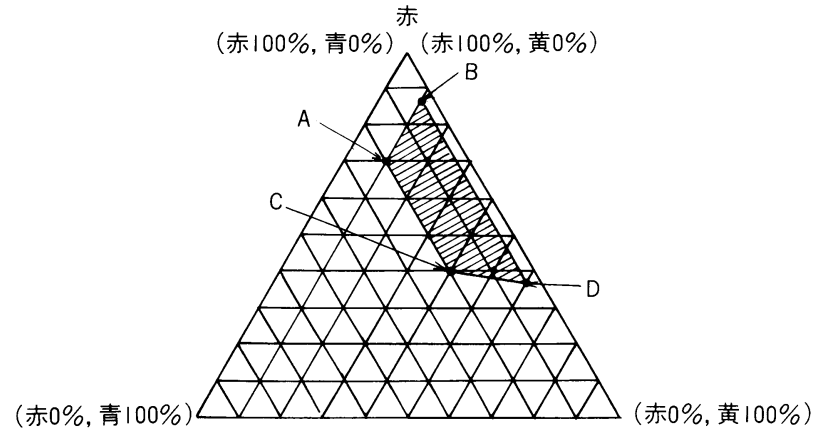

図 8-1 着色範囲 ${ }^{20)}$

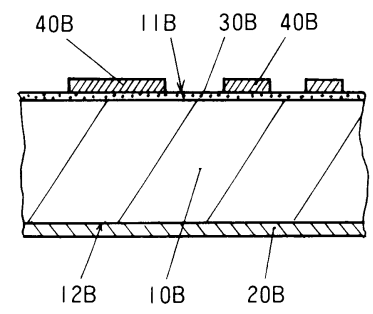

図 8-2 複写防止用紙 ${ }^{20)}$
写防止部分に貼り合わせるもの ${ }^{24)}$ 等がある。

\section{3 鏡面反射方式}

この方式は複写機の光学系の特徵を利用したもので, 複写すると全面が黒色になってしまうものである。図 9 に静電複写機の露光系の例を示したように, 光源か ら発生した光は反射板により集光されて原稿をセット するコンタクトガラスを通過して原稿に到達し, 画像 部分は吸収され非画像部分は反射されてミラーを通り 最終的には感光体に潜像を形成する。この反射の経路 は照射された原稿面からほぼ垂直に反射された光のみ が感光体に達するように設計がなされている。即ち画 像形成には露光の一部が有効な画像形成に関与してお りこれは原稿面が乱反射することによって生ずる垂 直光が寄与している。一般に光源からの光の入射角は 30〜 40 , 感光体に達する光は原稿面を 100 として数\% 程度である。

鏡面，例えば鏡をコンタクトガラス上に置いて複写 を行うと全面が黒色の複写物が得られる。つぎに鏡と コンタクトガラスとの角度を変えていくと, 或る角度 で全面が白色の複写物が得られるが，これは光の入射 光と反射光とが鏡面で正反射をしていることを示すも ので，鏡をコンタクトガラスに密着させた場合は反射 光が入射角と等しい角度で反射されるため垂直光は発

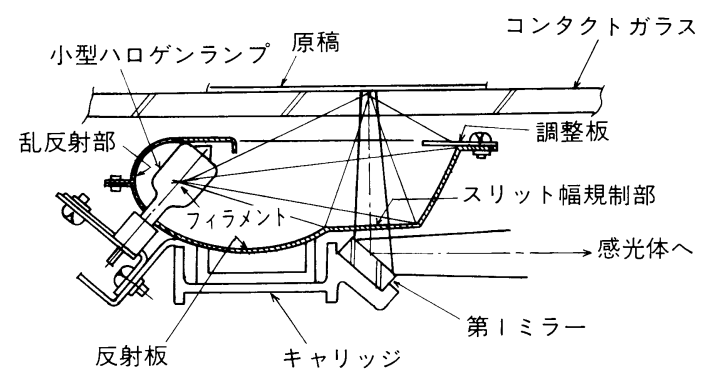

図 9 露光系概略
生せず, 鏡の角度を変えていくと, 或る角度で垂直光 のみの反射光となるために起こる現象で，原稿からの 垂直光がなければ感光体には光は達しないため画像形 成が起こらず複写されないことになる。

この原理を応用した複写防止が鏡面反射方式であり， 主にフィルムに金属蒸着したものが実用化されている。 この方式では光が正反射することが必須条件であり， 一般に表面は光沢のある金色や赤褐色で光の反射によ り原稿が読みづらい。またコンタクトガラスと原稿と の間に光を散乱させる半透明の材料を挿入すると, 乱 反射によって垂直光が発生して感光体に潜像が形成さ れてしまうため複写防止効果がなくなる欠点を有して いる。そのため他の方法との組み合わせによる出願が 多い。

特許出願はすでに金属蒸着による力式が昭和 52 年 に実用新案で出され 57 年に公告になっている ${ }^{25)}$ 。公開 特許にはアルミニウム等の金属薄膜の反射膜を設けた フィルムを複写防止すべき書類の上に付すもの ${ }^{26)}$, 金 属粉, フレーク, 蒸着物等をコーティングしたもの ${ }^{27)}$, 金属薄膜表面に四柄を加えたもの ${ }^{28)}$ ，鏡面をもった黒 体の不透明なシートと透光するフィルムとを重㸚接合 したもの ${ }^{29)}$ PPCによる原稿作成が出来るように金 属膜を全面連続膜でなく島状に形成し，その上に絶縁 層を設けたり, 図 10 に示したように所定の間隔で絶縁

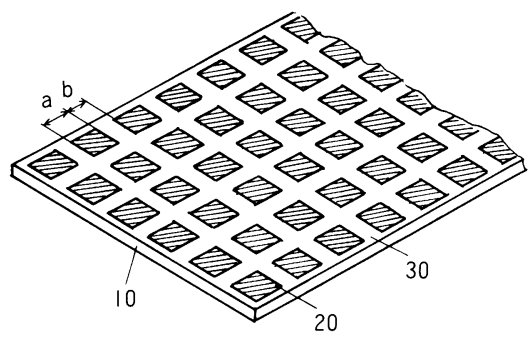

図 10 再複写防止フィルム (実開平 2-7654) ${ }^{30)}$ 
された金属蒸着層を設けたものや, 高光沢性合成樹脂 層を施した再複写防止用のもの等 ${ }^{30)} の$ 出願がある。

鏡面反射とは多少異なるが，反射を利用した発明と して，書類に光を乱反射するシートを貼着するもので， 例えば書類を垂直からは読めないレンティキュラース クリーンを付けたもの ${ }^{311}$ ，乱反射させるための凹凸に

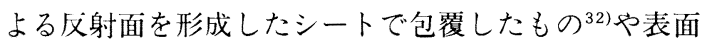
が乱反射する金属䈃を用紙の所望部分に貼着するも $の^{33)}$ ，光の入射光が反射して再び入射光の方向に戻る 再帰反射型の，例えばガラスビーズ層を設けたもの ${ }^{34)}$, 所定の方向に反射または乱反射させるスリット溝を有 するシートを書類上に設けたもの ${ }^{35)}$, 虹彩層を設けた もの ${ }^{36)}$, ルーパーフィルムを貼付したもの ${ }^{37)}$, 金属蒸着 層にガラスビーズ入りインキで印刷したもの ${ }^{38)}$ 等多数 の提案がなされている。

\section{4 光变色方式}

複写機の露光照射により化学的に変色（着色または 消色）する材料を用いて複写を防止するもので，化学 変化が非可逆性のものと可逆性のものとが提案されて いるが, 実用的にはフォトクロミック性を有する可逆 性材料が好ましい。例えば，露光照射により発色する 場合は通常は原稿は着色していないが，複写をすると 非画像部が露光により光励起され発色し, 画像部との コントラストがなくなり複写されず, 原稿の非画像部 は再び元の無色の状態に戻る。通常は非画像部分の着 色はないために原稿の判読性は良い。

この方式ではフォトクロミック性材料の探索がキー ポイントであるが, 光源の分光波長域, 紫外部放射工 ネルギーの不足, コンタクトガラスによる紫外部の吸 収などから, 現在のところ複写機の露光照射により発 色し, 通常使用の証明下では発色しない材料は見当な らないようである。

試算では原稿面露光量は $200 \sim 500 \mu \mathrm{J} / \mathrm{cm}^{2}$ 程度で あり，一般のスピロピラン系フォトクロミック材料の 発色光感度は数 10 数 $100 \mathrm{~mJ} / \mathrm{cm}^{2}$ 程度と推定され, 感度的にも通常の複写条件下では発色は困難と考えら れる。安価で濃色, 例えば黒色に発色するフォトクロ ミック材料が見当たらないことも実用化に対しての大 きな課題である。

この方式による特許出願は少ないが, 変色層として 高感度の銀化合物を用いたもの ${ }^{39)} の$ 他に昭和 64 年に

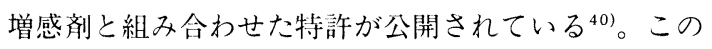
発明ではスピロピラン系フォトクロミック材料に増感 㓲としてジヒドロキシ-1,2 アントラキノン, アミノ -4 アセトフェノン, フェニルー4 アセトフェノン等をマイ ロクカプセルに包含して使用している。原稿は照射後
数秒で元の状態に復帰するが, 使用時の不用意の着色 を避けるために文書は中程度の照明下，例えば約 50 ルックスの明るさのもとで取扱いをすること, さらに 着色剂の併用を提案している。

露光によって消色する方式の提案もある ${ }^{41)}$ 。基紙に 可視光線によって基紙の表面色と異なる色に発色し, 紫外線により消色する逆フォトクロミック材料を塗布 したもので，表面色と同色のトナーで画像を形成する ことによって可視光下では画像の判読は可能であり， 複写時には紫外部の照射によって消色し画像は得られ ない。例えば基紙が白色である場合には白色トナ一, 逆フォトクロミック材料としステンハウゼ塩, チオニ ン塩等を用いることによって作成する。

\section{5 熱変色方式}

通常の複写機は光源, 画像定着部, その他の熱源に より発散される熱でコンタクトガラスの表面温度は $40^{\circ} \mathrm{C}$ 以上に上昇している。この方式は後述のサーモク ロミック性トナーやインキを用いる場合と同様に，こ のコンタクトガラス面及び露光照射時の熱を利用して 化学的に変色するサーモクロミック材料を用いて複写 防止を行う方式である。

常温では無色であるサーモクロミック材料を基紙に コーティングした複写防止用紙を用いて作成した原稿 で複写を行うと複写機の熱により発色して光変色方式 と同様に画像部と非画像部とのコントラストがなくな り複写は不能となる。この原稿を常温に戻せば消色し て非画像部は元の無色の状態になる。この方式ではコ ンタクトガラスに原稿をセットした時点で，すでに発 色が見られ熱応答性の問題は少ないと言える。テスト の結果では, 露光時の照射エネルギーによる発色より もコンタクトガラス面の熱による発色の寄与が大きい ようであった。また複写機のコンタクトガラスの温度 が発色温度以上にならないと作動しない機構を取り入 れればより確実に目的は達成できるものと思われる。 非画像部は無色であるために原稿は読みやすいが，熱 による発色のために通常の取扱い環境，例えば周囲温 度や体温では発色しないが，複写時には発色する条件 設定が課題であり, 発熱の少ない複写機対策も考える と, コンタクトガラス表面をサーモクロミック材料の 発色温度以上に保つような複写機側からの対応も必要 であろう。

この方式に関する用紙の出願は少ない。サーモクロ ミック材料として加熱発色型のロイコ系発色剤と顕色

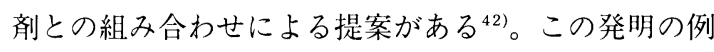
では図 11 に示したように基紙に感熱記録紙に用いら れる黒色に発色する無色のフルオラン系のロイコ染料 
(A)

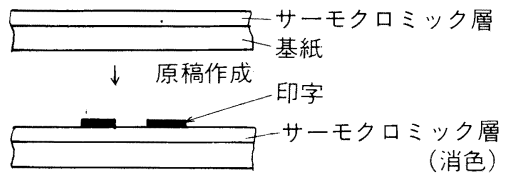

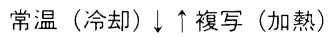

(c)

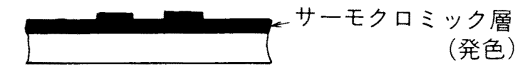

図 11 熱変色方式例 ${ }^{42)}$

と可逆的に発消色させるためのフェノール系顕色剂お よび発色温度を制御する高級アルコール類をマイクロ カプセルに包含したサーモクロミック材料を塗布した 複写防止用紙（A）の上に情報を記録する。この状態 では非画像部分は無色（B）であり原稿の判読性は良 い。この原稿を用いて複写を行うと複写機の熱により 無色のロイコ染料と顕色剛が溶融接触して反応し発色 (C)により画像部分と非画像部分とのコントラストが 失われ複写は出来なくなる。原稿を常温に戻すと可逆 的に元の状態 (B) に復帰するというものである。

\section{6 光発光方式}

この方式では原稿の光発光層が複写時の露光により 発光することによって複写物は目色の状態となり複写 不能とするものである。露光により原稿の全面が均一 に発光するためには画像部分も非画像部と同程度に発 光する必要があり, 非画像部の発光のみで曲像部分ま で均一に発光させることは困難と思われる。発光性の トナーやインキを用いる出願もなされているが, 用紙 の場合には原稿作成後発光性材料の塗布処理を行うか, 或いは発光性のフィルムを貼り合わせることが考えら れる。実用化には特に通常の複写による露光条件下で の発光効㻭の良い材料の開発が課題とされる。このオj 式の出願は少ない。

実施例による詳細の記載はないが, 光放射物質とし て化学蛍光剤, 例えば複写機のハロゲンランプの特定 紫外線により兴光を発する性質を有するアクリル材料 や光蛍光剤, 或いは紫外部から近赤外部の範网の入射 光線を $98 \%$ 以上反射する硫酸バリウム等を用いる提 案がある ${ }^{43)}$ 。他の例として色トナーを用いたものが 提案されている ${ }^{44)}$ 。紫外線発光物質として例えば無機 系の燐光体を使用し，この紫外線発光物質を塗布また は含浸させた用紙に白色トナーで画像を形成して原稿 を作成する。この原稿はそのままでは判読は不能で, 複写しても白色の状態である。情報の再現は紫外線照 射の下で発光した非画像部の中に非発光体の白色卜 ナ一像を明瞭に判読することができるという発明であ
る。

\section{7 光吸収方式}

この方式は画像部, 非泫像部其に簬光による光を吸 收して複写物が全洎が貹色となるもので, 现象は着色 方式と同様であるが，この方式では䏳紙は染顔料で着 色されていないのが特徴である。着出う圪と比較して 用紙が無色入は淡色であり判涜性も優れ好ましい複写 防止方式であるが，現笑には無色の状態で露光による 光を效率良く吸收する材料の探少が難しくこの)j式の 出願も少ない。

作用についての理論的根拠はイ明としながらも照射 光吸収材料として料子栙 $0.7 \mu \mathrm{m}$ 以下の酸化チタン微 粒子および/または粒子径 $10 \mu \mathrm{m}$ 以卜の亦外線吸収 性がラス微粒子を用いた提案がされている タン微粒子ははチル型の半透明または透明な酸化チ夕 ンが好ましく, 赤外線吸仪性:ガラス微粒子はは金属酸化 物を含有したガラス微粒子で则眼では多どけ色入は淡 色でありながら複写すると罢出に筹出された複年物が 得られるというものである。

光吸収戍として, 例えば図 12 の構造式で表わされる 八ロゲンコンプレックスを䏘いた提案もある゙6)。記載 によればこのものは多㑛，無毒であり，原稿の表面に コーティングすることによってその原和を複軍不可能 な複写防止文書とすることができ，スタンブインキの ように部分的にコーティングすることもできる。

\section{8 複写防止インキ, トナーを用いる方式}

この方式は特殊なインキ，トナーにより恼像を形成

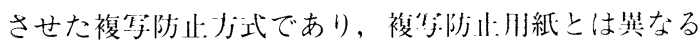
が，特に原稿你成，あるいは印们インキ，トナーとし ての用途がある。一般に胿紙は加にされていないため に通常の印刷物と闰様に原稿は諳みや寸い。

作用は特定波拄分光吸收, 発光, フォトクロミズム, サーモクロミズム等の特性を利川しな提案が多い。複 写機光源の分光特性と感光体の分光感度特性から選定 された分光父射摔特性を有するトナーを用いるもの ${ }^{47}$,

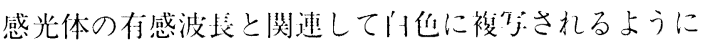
発光する特定の省光物質を会们させたもの ${ }^{48)}$, 特定の

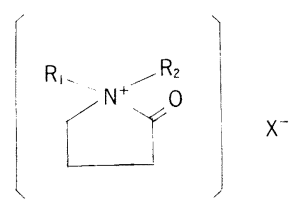

$X:$ ハロゲン

$\mathrm{R}_{1}, \mathrm{R}_{2}$ : アルキル基

図 12 ハロゲンコンブレックス光吸仪剂 ${ }^{46)}$ 
蛍光体, 例えば紫外部発光蛍光体 $\left(\mathrm{BaSi}_{2} \mathrm{O}_{5} \cdot \mathrm{Pb}\right.$, $\mathrm{Sr}_{2} \mathrm{P}_{2} \mathrm{O}_{7} \cdot \mathrm{Eu}$ 等) 又は赤外部発光蛍光体 $((\mathrm{Sr}, \mathrm{Mg}$, $\left.\mathrm{Ba})_{3}\left(\mathrm{PO}_{4}\right)_{2} \cdot \mathrm{Sn}\right)$ を含有させたトナーを用いるもの ${ }^{49)}$ や露光時の温度で消色するインキ, トナーを用いるも のとしてはサーモクロミック材料に無色のロイコ系染 料と顕色剂との組み合わせによる可逆性熱变色材料を 用いた出願が数社からなされている50)。これらは通常 の環境下では支障なく読めるが，複写の際の熱により 消えて複写はできなくなり常温に戻せば再び画像が現 われるもので熱変色方式と同様に発色温度の確保が課 題である。波長 $400 \mathrm{~nm}$ 以下の光を吸収する紫外線吸 収剤（例えばサリチル酸フェニル系, ベンゾフェノン 系，ベンゾトリアゾール系）を含有する透明トナーが 提案されている ${ }^{51}$ 。通常は画像は判読できないため複 写されないが, ジアゾ感光紙上に複写することにより 可視像化することができるというものである。

着色剂が蛍光黄色染料で着色され，400５00 nm の 波長範囲において吸収ピークを示し, 且つ反射率が $70 \%$ 以上である着色球状粒子を含有するインキ組成物 の提案がある ${ }^{52)}$ 。これは入射光が再帰反射するために 基紙と文字との反射率は接近し, その結果, 複写不能 となるが，肉眼では黄色蛍光により判別を容易にした ものである。

ブルー系の色のインキ, ペンシルが複写されない筆 記具として市販されている。イエローの蛍光ペンでも アンダーラインのマーキングを行った書類を複写して もアンダーラインの部分は複写されないが，これらは 濃度も低く色も限られるために通常の書類の印字用と しての使用には向かない。

最近，カナダから用紙とインキの組み合わせによる 複写防止用品が発売された。無色の特殊な用紙に印字 した原稿の複写防止したい部分を無色の特殊インキの 筆記具でなぞると赤褐色に発色し，このものを複写す ると発色部分は黒く複写されてしまう。材料は無色の ロイコ系染料を塗布した用紙とそれを発色させるため の顕色剤溶液の無色のインキからなっている。

マーキングにより発色した部分の判読性および複写 防止性は着色方式と同程度である。

\section{9 複写装置と連動させた方式（センサー検知方} 式)

この方式の代表的なものは原稿の特定部分を複写機 側のセンサーで検知して複写の作動を停止させるもの で検知の方法として多くの出願がされている。

この方式は複写防止用紙と複写機との組み合わせに よるために, 複写防止機能の発現は特定の用紙と特定 の複写機に限られることから汎用性にはそしいが, 或
る限られたエリア，例えば特定のオフィス，建物，敷 地内等では効果が大きい防止手段と言える。

主な検知用材料として次のものがある。

(1) 磁気材料 ${ }^{53}$

(2) 金属材料 ${ }^{54}$

(3) 赤外線吸収剂55)

(4) 紫外線吸収剂 ${ }^{56)}$

(5) 蛍光材料 ${ }^{57)}$

用紙の構成は検知材料を用紙全面に塗布したもの， 積層状にしたもの，用紙の特定部分に設けたもの等あ るが, マークのように特定部分にのみ設けた場合には 部分的に複写される危険がある。

制御方法としては検知材料からの識別情報を読み 取って複写機能を停止させるものの出願が多いが, 所 定の識別情報のみ複写機能を開始させるもの ${ }^{58)}$, 識別 情報を検知し警報を発するもの等がある。図 13 に検 知用材料に金属を用いたこの方式のシステムの 1 例を 示す。シート 1 の裏面がアルミニウム等の薄い蒸着層 2 で構成され，この用紙で作成した原稿 3 はコンタク
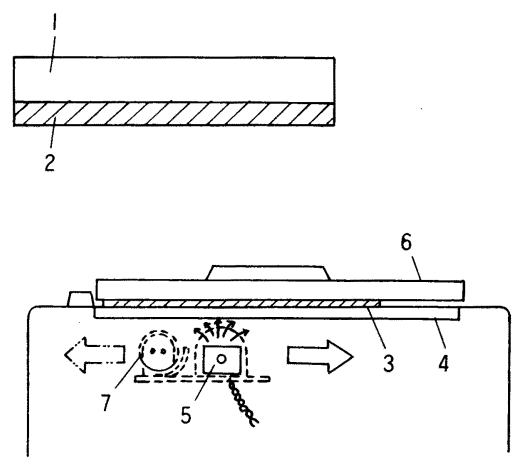

図 13 センサー検知方式（特開昭 60-19170） ${ }^{54)}$

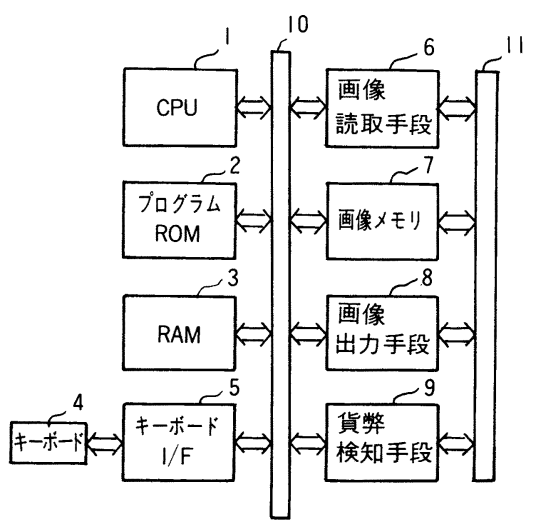

図 14 複写制御方式フロー (特開平 1-285977) ${ }^{61)}$ 
トガラス 4 上で複写機側の近接検出器 5 により金属の 有無が確認され複写動作を制御するものである。この 他にマイクロ波減衰特性を検出するもの ${ }^{60)}$, 高精度の カラー複写機の普及により, 特に紙幣, 有価証券等の カラー複写防止用として画像デー夕読み取り手段, 判 断手段等をそなえたカラー複写装置の出願もなされて いる ${ }^{61)}$ 。図 14 にこの発明の制御方式のフローを示す。

\subsection{0 その他の方式}

偏光性の着色層を有するシートを用いて着色層と同 一又は類似の色調で記録し, 特定の偏光フィルターを 重ねて見ることによって着色層は淡色となり情報が再 現されるもの ${ }^{62)}$, どの角度からも偏光方向がランダム になるように偏光体を用紙と複写機側に設け，原稿は 判読できるが複写すると偏光によって判読不能となる もの ${ }^{63)}$ ，干渉縞が生じるように配設された線材群を有 するもの ${ }^{64)}$ ，角度によって色が変わって見える光干涉 フィルムを設けたもの ${ }^{65)}$, 記録面の上に凹凸状の 2 枚 のフィルムを重ねて接着することにより，反射で記録 は判読されないが，凹凸の間吵に液体を入れて可視化 を可能とするもの ${ }^{66)}$, 光を吸収して発熱性のない黑色 用紙に黒色トナーで原稿を作成し, 可視化は感熱孔版 印刷により行うもの ${ }^{67)}$ ，原稿に複写機の光源の焦点が 合わないようにプレートを設けて，コンタクトガラス 面へ正しくセットできない特定の原稿としたもの ${ }^{68)}$ 等 が出願されている。

\section{3. 現状と将来動向}

1985 年頃からカナダの Nocopi 社から複写防止用 紙として “Nocopi Paper”が Pulp \& Paper 等に紹介 され関心を集めてきた69)。Nocopi International Inc., が特許 ${ }^{70)}$ を持つこの複写防止用紙は抄紙の過程でビー ター中でパルプに開発した特殊な染料を混合して紙に 抄きこんだ赤褐色の着色方式による複写防止用紙で, 機密性に応じて 3 つのレベル 5 種類の製品があり機密 性の最も高い“WordSafe Scrambler”は濃色で, さ らに地紋印刷が施されている。着色と地紋印刷のため に作成した原稿の判読性は悪く特殊紙の感じは強い。 用紙の製造は Hammermill Paper Co.'s Erie, Pa., mill, Wausau Paper Mills Co., Brokaw, Wis. で行わ れ, 染料の供給は Bayer AG のディビジョン Mobay Chemicals, 地紋印刷は別会社で行っており，1986 年 発売時点では小売価格 4 25£/枚で年 8,000 億枚と予 想される全世界のコピーペーパー市場の $0.5 \sim 1.0 \%$ を目標に置いていたが約 3 年間で 2.5 億枚を販売した 模様である。複写もファクシミリ送信も不可能という ことで政府・官公庁，軍，保険会社，銀行，一般企業，
学校関係等の市場に, 用途もコンピュータゲームマ ニュアル，コストシート，ビデオショップバーコード， 大学の成績表等の用途にまで広範用な市場に, 特に米 国のシリコンバレーや欧州で着実に安定した市場を伸 ばしているようである。代理店の話では最初に出した 製品はブドー酒色で反射率も低く読みにくく，タイプ ライターなどで印字するとへこんで複写されやすく なったりするが，多少の読みにくさは我慢して使用し ているようである。改良品として上市を計画している 読みやすい“イエローシート”は現在の製品とは全く 異なる方式のものでコーティングにより製造し, 通常 は淡色で複写時に着色して複写物は全面黒色で判読で きなくなり 原稿は 20 分で元の状態に戻り室内光, 太 陽光の下では着色しないということであり，フォトク ロミック材料を用いたものと見られるがサンプルは入 手出来ていないのでどの程度の性能か不明である。価 格は $4 £ /$ 枚になるだろうとのことである。

国内での参入メーカーはキソ化成産業, 細川活版所, 凸版印刷，大日本印刷，富士ゼロックス等数社があり， 偽造防止用紙を除くと実用化されている複写防止用紙 は着色方式および鏡面反射方式（フィルム）が主で, 昭和 63 年に調查した市場規模は図 15 に示した結果で あった。

用途は各社共一般企業に於ける社内機密文書用が 90\%近くを占め次が官公庁関係となっている。

偽造防止用紙を含めた主な製品別の用途は次のよう である。

偽造防止用紙

印鑑証明，住民票，証券印刷

複写防止用紙

一般企業機密文書（設計図，販売情報，仕様書） 官公庁機密文書, 出版物

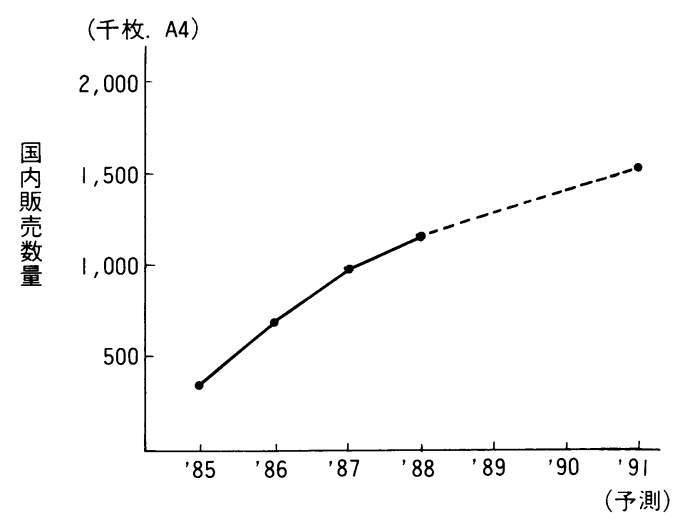

図 15 複写防止用紙国内販売数量 
複写防止フィルム

機密文書の全面又は部分的隐蔽

複写防止インキ, トナー

機密文書, 出版物 (学術書, 参考書, 楽譜)

機密文書の部分的隐蔽

各社共に理想とする複写防止用紙は地色は白色で複 写すると黒くなって読めない紙を考えているが, 複写 防止用紙としての要求項目を列挙すると

(1) 原稿の文字が読みやすい

(2) 複写した文字が判読できない

（3）容易には再複写の手段がない

(4) 原稿の作成, 使用操作が容易

(5) 普通紙並の取扱い感触

(6) 複写機の制約がない

(7) 複写条件の制約がない

(8) 経時劣化がない

(9) 価格が安い

等で技術課題として解決の困難な項目も多いが, 現在 は(1)及び(2)の原稿の読みやすさと複写防止性能が最重 要課題となっている。

方式別に見て技術的に新なな展開がない限り各社共, 今後も複写防止方式は着色複写防止用紙, 鏡面反射複 写防止フィルム及び複写防止インキ, トナーの改良,

開発を考えているようである。

着色複写防止用紙は複写防止機能を落とさずに着色 を少なくし，原稿が読みやすくなれば市場の拡大が望 めるために特に改良に注力しているが，メーカー各社 が大いに期待している出版物の違法複写を問題にして いる出版業界では文字が見にくいこと, 複写防止性能 が不十分であること，価格が高いこと，複写防止効果 をなくす機械が必ず出現する等により現在はあまり過 大の期待はしていないようである。

現在, 実用化されている製品は各社共に満足のいく ものはなく，汎用性に乏しいもので，今後かなり改良 しなければューザーの期待には応えられないと思われ る。

鏡面反射複写防止フィルムは原稿の全面又は一部に 貼って使用するため原稿の文字が見にくく，高価であ り, 大量に使う再複写防止用や印刷用には使用されな いために大幅な伸びは期待出来ない。特徴を生かして 機密文書の部分隐蔽の用途が有望であろう。最近発表 された複写防止用紙 ${ }^{71)}$ は表面はアルミ蒸着と特殊な顔 料の 2 層構造で, その上に印刷可能な表面に樹脂加工 処理が施され, 複写用紙としても使用出来, フィルム の欠点を改善したものと思われる。

複写防止インキ, トナーは印刷インキ並の特性に近
い複写防止インキが開発されれば印刷業界を中心にか なり大きな市場が形成される可能性は大きい。要求品 質を満足させるには特殊な材料及び構成の開発に時間 を要するものと考えられる。

各方式別に技術課題について整理した結果を表 1 に 示した。

\section{4. おわりに}

複写による文書偽造, 機密情報の漏洩や出版物等の 違法複写問題により複写防止に対する関心が高くなっ ているが, 本稿では複写防止用紙を中心に主に特許情 報から技術の動向及び現状について概観してきた。

現在, 可視記録情報はその殆ど全てが一般に普及し ている複写機で複写可能となっており, 複写防止に関 する方式には様々な提案がなされているが, 中には理 論的に困難なもの, 実用性の乏しいと思われるもの等 もあり，現実には市場に出ているものは少なく，また 複写防止機能は十分とは言えない。さらに複写方式の 多様化, カラー化, デジタル化, 多機能化の技術開発 も著しく, 新複写プロセスの開発も盛んに進められて おり, 複写防止技術は複写技術の進歩に追いつけず, 現在ユーザーの期待に応え得る複写防止方式は見当た らないのが実情である。

着色防止は機密文書を着色することによって重要書 類であることを識別認識させ，機密書類の取扱いに対 する注意を喚起し, 一方不正複写を牽制する価值があ ると言うメーカーもあるが, これは複写防止技術の難 しさを物語っているとも言えよう。企業からの機密書 類漏洩防止の要望や出版業界からの原本複製厳禁の声 が頻繁に聞かれるようになってからかなりの年月が経 過している。投稿中にも機密資料を複写して盗み出し 数社に売り込んでいた疑いで逮捕された機密文書流出 事件が報じられた ${ }^{72)}$ 。

機密保持, 違法複写に対するニーズは高く非常に大 きな市場が期待され, 複写防止についての多くの提案 がなされてきたが, ユーザーの望んでいる複写防止用 紙は技術的には現在の技術の延長では非常に難しく， どのように技術のブレークスルーをするかが大きな課 題となっている。

一方，ユーザー側の複写防止用紙の使われ方も様々 で，例えば再複写防止用紙の場合には機密書類を持ち 出さずに，その場にある複写機で複写して書類は元の 場所に戻し複写物を持ち出す場合の対策や機密会議資 料の再複写を防ぐ場合が多く, また印刷業界での書籍 に対する複写防止の場合には，広範囲での複写防止対 策が要求される。現在文書作成及び複写, プリントの 


川村栄—

表 1 複写防止方式別技術課題

\begin{tabular}{|c|c|c|c|}
\hline 方 & 特 & 課 & 対 \\
\hline \multicolumn{4}{|l|}{ （用紙） } \\
\hline 地紋印刷方式 & $\begin{array}{l}\text { 偽造防止 } \\
\text { 違法複写警告 }\end{array}$ & $\begin{array}{l}\text { 複写防止性 } \\
\text { 原稿判読性 }\end{array}$ & $\begin{array}{l}\text { 他方式との組み合わせ } \\
\text { 偽造防止用途向け } \\
\text { 違法複写警告用途向け }\end{array}$ \\
\hline 着色方式 & $\begin{array}{l}\text { 汎用性 } \\
\text { 識別管理 } \\
\text { 低コスト }\end{array}$ & $\begin{array}{l}\text { 原稿判読性 } \\
\text { 濃着色 } \\
\text { (複写防止性) }\end{array}$ & $\begin{array}{l}\text { 他方式との組み合わせ } \\
\text { 最適色素設計 }\end{array}$ \\
\hline $\begin{array}{c}\text { 鏡面反射方式 } \\
\text { (フィルム) }\end{array}$ & $\begin{array}{l}\text { フィルム } \\
\text { 透明性 } \\
\text { 部分防止 }\end{array}$ & $\begin{array}{l}\text { 原稿判読性 } \\
\text { 用途限定 } \\
\text { コスト }\end{array}$ & $\begin{array}{l}\text { 他方式との組み合わせ } \\
\text { 特殊用途向け }\end{array}$ \\
\hline 光発色方式 & 原稿判読性 & $\begin{array}{l}\text { 発色光感度 } \\
\text { 発色濃度 } \\
\text { 判読時の発色 }\end{array}$ & $\begin{array}{l}\text { 特定波長域応答性材料 } \\
\text { 黒発色材料 } \\
\text { (難度大) }\end{array}$ \\
\hline 熱発色方式 & 原稿判読性 & $\begin{array}{l}\text { 発色熱源 } \\
\text { 発色応答速度 } \\
\text { 判読時の発色 }\end{array}$ & 発色温度保持複写機 \\
\hline 光発光方式 & 原稿判読性 & $\begin{array}{l}\text { 露光時発光強度 } \\
\text { 複写防止性 } \\
\text { 全面均一発光 }\end{array}$ & 強発光材料設計 \\
\hline 光吸収方式 & 原稿判読性 & $\begin{array}{l}\text { 光吸収強度 } \\
\text { 複写防止性 } \\
\text { 全面均一吸収 }\end{array}$ & \multirow[t]{2}{*}{$\begin{array}{r}\text { 光吸収性無色材料設計 } \\
\text { (難度大) }\end{array}$} \\
\hline (インキ) & & & \\
\hline フィトクロミック方式 & $\begin{array}{l}\text { 原稿判読性 } \\
\text { 普通紙 }\end{array}$ & $\begin{array}{l}\text { 消色感度 } \\
\text { 印字安定性 } \\
\text { コスト }\end{array}$ & 特定波長域応答性材料 \\
\hline サーモクロミック方式 & $\begin{array}{l}\text { 原稿判読性 } \\
\text { 普通紙 }\end{array}$ & $\begin{array}{l}\text { 消色熱源 } \\
\text { 消色応答速度 } \\
\text { 印字安定性 }\end{array}$ & 消色温度保持複写機 \\
\hline 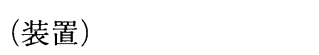 & & & \\
\hline センサー検知方式 & $\begin{array}{l}\text { 原稿判読性 } \\
\text { 複写防止性 } \\
\text { デジタル対応 }\end{array}$ & $\begin{array}{l}\text { 特定複写機 } \\
\text { 使用範囲限定 } \\
\text { 市場機対策 }\end{array}$ & 特定用途向け \\
\hline
\end{tabular}

デジタル化によりソフト側からのセキュリティ対策も 進められており, 今後複写防止方式, 材料等の再検討 による技術的なアプローチとともにマーケティングに よる特定の目的, 用途, 分野に応じた対応が必要とな るものと考える。

\section{引用文献}

1）特開昭 52-76117 凸版印刷

2) 特開昭 60-79991 細川活版所 実開昭 61-122869 細川活版所 実開昭 61-138563 細川活版所

3）特開昭 60-87380 細川活版所 特開昭 61-10482 富士ゼロックス 
特開昭 61-89085 富士ゼロックス 特開昭 62-170964 細川活版所

4）特開昭 58-38188 細川活版所 特開昭 61-95993 アムテック 特開昭 63-256980 細川活版所

5）特開昭 54-118822 凸版印刷 特開昭 57-20395 細川活版所 実開昭 61-28675 細川活版所

6) 特開平 1-167870 大日本印刷

7）特開平 3-152583 キソ化成産業

8）特開平 2-29679 大日本印刷

9) 特開昭 2-81698 細川活版所

10）特開昭 54-52538 富士ゼロックス 特開昭 60-244588 奈良和裕 特開平 1-214887 谷口インキ

11）特開昭 63-301081 巴川製紙所

12）特開昭 51-16030 並木啓志

13）特開平 1-263686 大日精化工業

14）特開昭 61-5996 細川活版所 特開昭 63-139797 細川活版所

15）特開昭 62-296154 赤司泰三

16）特開昭 62-177076 東洋インキ

17）特開昭 61-130083 東洋インキ

18）特開昭 58-158674 アゾナ

19）特開昭 63-314583 ノーコピイインターナショナ 儿

20）特開昭 63-71875 キソ化成産業 (特開昭 64-42678)

21）特開昭 63-87297 細川活版所

22）特開昭 63-256980 細川活版所 (公告 平 1-54706)

23）特開昭 59-174870 ノーマンエーガードナー

24）特開昭 60-48065 細川活版所 特開昭 61-23187 キソ化成産業 特開昭 61-86282 モダンプラスチックス工業 特開平 2-220087 オカモト

25）特開昭 53-166935 リコー (公告 昭 57-42698)

26）特開昭 55-96973 与那原好宏 実開昭 58-138670 凸版印刷 特開昭 60-191283 凸版印刷 特開昭 62-199899 大日本印刷 実開平 1-85761 三田工業

27）特開昭 61-35985 大日精化工業

28）実開昭 58-168754 細川活版所 実開平 1-85762 細川活版所
29）特開昭 61-219637 三菱重工業

30）特開昭 62-176874 尾池工業所 特開平 1-138567 三田工業 実開平 1-176846 56 三田工業 実開平 2-7654 58 三田工業 特開平 4-50887 大日本印刷

31）特開昭 53-83831 アロパーティシペイション 実開昭 58-101775 小林保一

32）実開昭 55-65652 与那原好宏

33）特開昭 60-262690 第一交商

34）特開昭 56-99358 リコー 特開昭 60-225782 奈良和裕

35）特開昭 62-94882 リコー

36）特開昭 60-13598 尾池工業所

37）特開昭 63-17462 エフエスケイ

38）実開昭 59-77101 凸版印刷

39）特開昭 55-38513 与那原好宏

40）特開昭 64-90480 S. A. VICAT（仏）

41）特開平 2-28683 ミノルタカメラ

42）特開平 3-224788 リコー 特開平 3-231888 リコー

43）特開昭 63-311374 セキュリティ・タグ・システム ズ (米)

44）特開平 2-23383 ジャパンメタリック

45）特開昭 63-254482 谷ロインキ

46）特開昭 64-73376 シャープ

47）特開昭 57-122460 富士ゼロックス

48）特開昭 58-14842 巴川製紙所

49）特開昭 63-311265 コニカ

50）実開昭 60-117183 パイロットインキ 特開昭 62-14163 富士ゼロックス 特開昭 63-8780 東洋紙業 特開平 1-154162 巴川製紙所

51）特開平 1-259374 三田工業

52）特開平 1-201382 大日精化工業

53）特開昭 56-126844 東京磁気印刷 特開昭 59-93465 富士ゼロックス

54）特開昭 59-23361 富士ゼロックス 特開昭 60-4964 富士ゼロックス 特開昭 60-19170 富士ゼロックス 実開昭 60-28760 山陽国策パルプ 実開昭 60-28761 山陽国策パルプ 実開昭 62-188782 富士ゼロックス

55）特開昭 59-9681 富士ゼロックス 特開昭 60-8880 富士ゼロックス 56）特開昭 60-8878 富士ゼロックス 
57）特開昭 58-184967 リコー 特開昭 59-135451 リコー

58）特開昭 54-36731 キャノン

59）特開昭 60-8879 富士ゼロックス

60) 特開昭 60-49379 富士ゼロックス

61）特開平 1-285977 キャノン 特開平 1-285978 キャノン

62）特開昭 62-23777 大日本印刷

63）特開昭 64-4784 巴川製紙所

64）実開平 1-85760 三田工業

65）特開平 1-155381 リパテクエスタブリスマン（ス イス)

66）特開昭 64-10284 スリーエステクノロジーズ（オ ランダ)

67）特開昭 63-246752 三田工業

68）特開昭 59-125771 富士ゼロックス
69) Pulp \& Paper Aug, 33 (1985)

Business Week industrial Edition Jun, 10, $110 \mathrm{~g}$ (1985)

Globe \& Mail Report on Business March, 29, sec B 3 (1986)

Pulp \& Paper Feb, 33 (1987)

Pulp \& Paper Week Aug, 15 (1988)

Pulp \& Paper April, 175 (1989)

70) USP 4522492 (1985)

USP 4632429 (1986)

USP 4867481 (1989)

71）日本経済新聞 1991 年 8 月 28 日号 特開平 4-60573 キソ化成産業 特開平 3-254997 東レ

72）日本経済新聞 1991 年 11 月 29 日号 